\title{
Techno-Economical Evaluation of Bio-Oil Production via Biomass Fast Pyrolysis Process: A Review
}

\author{
Abrar Inayat ${ }^{1,2 *}$, Ashfaq Ahmed ${ }^{3,4}$, Rumaisa Tariq ${ }^{5}$, Ammara Waris $^{6}$, Farrukh Jamil ${ }^{4}$, \\ Shams Forruque Ahmed ${ }^{7}$, Chaouki Ghenai ${ }^{1,2}$ and Young-Kwon Park ${ }^{3 *}$
}

${ }^{1}$ Department of Sustainable and Renewable Energy Engineering, University of Sharjah, Sharjah, United Arab Emirates, ${ }^{2}$ Biomass and Bioenergy Research Group, Center for Sustainable Energy and Power Systems Research, Research Institute of Sciences and Engineering, University of Sharjah, Sharjah, United Arab Emirates, ${ }^{3}$ School of Environmental Engineering, University of Seoul, Seoul, South Korea, ${ }^{4}$ Department of Chemical Engineering, Comsats University Islamabad, Lahore Campus, Lahore, Pakistan, ${ }^{5}$ School of Engineering, Monash University, Subang Jaya, Malaysia, ${ }^{6}$ Department of Zoology, Lahore College for Women University (LCWU), Lahore, Pakistan, ${ }^{7}$ Science and Math Program, Asian University for Women, Chattogram, Bangladesh

OPEN ACCESS

Edited by:

Abdul-Sattar Nizami,

Government College University,

Pakistan

Reviewed by:

Muhammad Abdul Qyyum,

Independent researcher,

Muscat, Oman

Muhammad Farooq,

University of Engineering and

Technology, Pakistan

*Correspondence:

Young-Kwon Park

catalica@uos.ac.kr

Abrar Inayat

ainayat@sharjah.ac.ae

Specialty section:

This article was submitted to

Bioenergy and Biofuels,

a section of the journal

Frontiers in Energy Research

Received: 03 September 2021

Accepted: 21 December 2021

Published: 13 January 2022

Citation:

Inayat $A$, Ahmed A, Tariq $R$, Waris $A$, Jamil $F$, Ahmed SF, Ghenai $C$ and

Park Y-K (2022) Techno-Economical

Evaluation of Bio-Oil Production via

Biomass Fast Pyrolysis Process:

A Review.

Front. Energy Res. 9:770355. doi: 10.3389/fenrg.2021.770355
Biomass pyrolysis is one of the beneficial sources of the production of sustainable bio-oil. Currently, marketable bio-oil plants are scarce because of the complex operations and lower profits. Therefore, it is necessary to comprehend the relationship between technological parameters and economic practicality. This review outlines the technical and economical routine to produce bio-oils from various biomass by fast pyrolysis. Explicit pointers were compared, such as production cost, capacity, and biomass type for bio-oil production. The bio-oil production cost is crucial for evaluating the market compatibility with other biofuels available. Different pretreatments, upgrades and recycling processes influenced production costs. Using an energy integration strategy, it is possible to produce bio-oil from biomass pyrolysis. The findings of this study might lead to bio-oil industryrelated research aimed at commercializing the product.

Keywords: fast pyrolysis, biomass, bio-oil, economic analysis, production cost

\section{INTRODUCTION}

Biomass is becoming the most promising alternative source for producing clean and sustainable products, because of its communal availability, relatively lower price, and zero harmful emissions (Li et al., 2004). According to a report, biomass accessibility is abundant for biofuel production worldwide (Trinh et al., 2020). Bioenergy is the energy derived from the different sources of biomass (Adams et al., 2018). Biomass originates from microbes and vegetation (Boran, 2018). It comprises all the organic and biological constituents from living organisms produced by direct or indirect processing (Nachenius et al., 2013). It can be classified further into agriculture biomass, forestry biomass, crops, wood-based biomass, municipal and industrial waste, food waste, animal and human-generated waste. Biomass is the fourth primary energy source and currently delivers $14 \%$ of prime energy (Tabakaev et al., 2019). Biomass can be transformed into biofuels through biological and thermal conversion approaches. On the other hand, the biological conversion approach is unstable at the commercial level because it employs all stresses on food-based raw materials (Naik et al., 2010). On the other hand, the thermal conversion approach, such as pyrolysis, gasification, and combustion, has a wide range of raw materials in a shorter period and deals with multiple and intricate biofuels (Bridgwater, 2012; Shahbaz et al., 2016; Ghenai et al., 2019; Inayat et al., 2020). These biofuels have variations in physicochemical composition and properties, which helps deal with unique practical and economic challenges (Shemfe et al., 2015). 


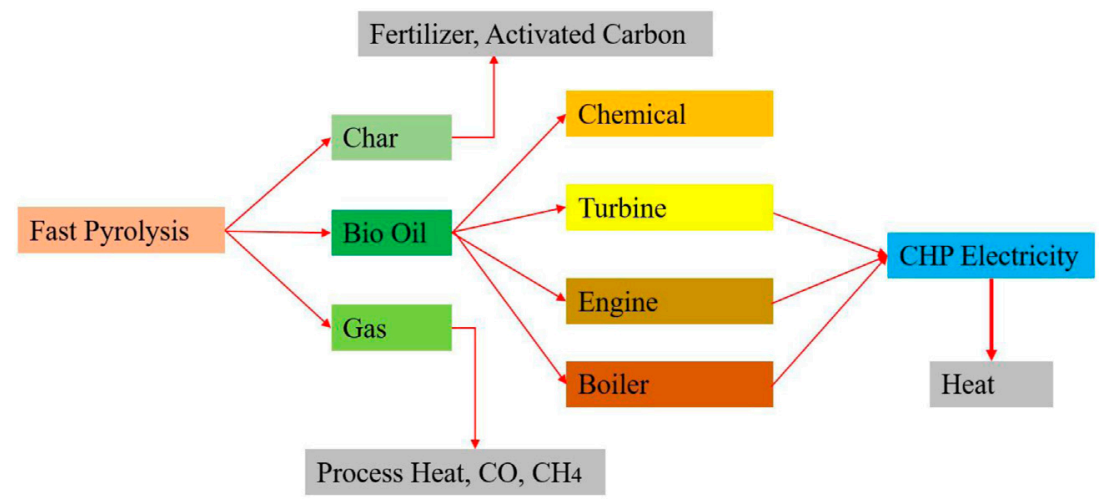

FIGURE 1 | Products of fast pyrolysis of biomass.

Fast pyrolysis is considered the most promising approach to generate liquid fuel, such as bio-oil, at its maximum extent among all these thermal conversion methods. According to an estimate, fast pyrolysis can produce up to $75 \mathrm{wt} \%$ bio-oil, which can be used in many applications directly or as an energy carrier after upgradation (Czernik and Bridgwater, 2004). Fast pyrolysis is a suitable process for converting biomass into bio-oil in an inert atmosphere at the medium temperature range from 400 to $600 \mathrm{C}$ using a short residence time of approximately $2-10 \mathrm{~s}$ and higher heating rates. Various conditions, such as raw material, reactor type, temperature, additives, catalysts, residence time, and pressure, greatly influence the performance and quality of the product (Zhang et al., 2011). Bio-oil obtained from fast pyrolysis contains oxygenated organic compounds and water, making it unstable and corrosive. Therefore, upgrading is necessary for deoxygenation to make it compatible with refinery fuels (Sorunmu et al., 2020).

Many research articles have been published on optimizing bio-oil production from various biomass using a fast pyrolysis process under different operating conditions (Chen et al., 2019; Nzihou et al., 2019; Marathe et al., 2020). On the other hand, there is a lack of information on economic analysis comparison on fast pyrolysis process to make it commercially stable. The commercial practicability of bio-oil is based on reducing the manufacturing cost, enhancing the product quality, and improving accessibility to an abundant and sustainable source of biomass. Economic analysis is a helpful strategy to assess the potential of the process to scale up using product cost prediction (Kim and Parker, 2008). Economic analysis can be done using different approaches with an experimental study and developed mathematical models to make any process feasible at the market level (Zhang et al., 2013). Literature showed many research papers and case studies published on the economic analysis of pyrolysis used for bio-char and bio-oil production. There is a need to provide a platform specifically for economics analysis and cost of the bio-oil output using a fast pyrolysis process. This work aims to provide valuable information on the economic evaluation of bio-oil produced by different biomass via the fast pyrolysis process.

\section{BIO-OIL PRODUCTION VIA FAST PYROLYSIS}

Fast pyrolysis is a technique of changing different biomass types in the absence of air or $\mathrm{O}_{2}$ to generate three types of products based on their nature, i.e., solid char, liquid oil, and volatile gas, by thermal breakdown of the material. Pyrolytic gas is generated in this process. A dark brown homogenous liquid is produced with a high heating value known as bio-oil upon cooling and condensing. Figure 1 shows the schematic diagram of biomass pyrolysis (Bridgwater, 2017). Three main products (biochar, biooil, and syngas) are produced from the fast pyrolysis of biomass. Bio-oil can be used as a fuel in engines and boilers, used further for electricity and heat production via combined heat and power (CHP) plants. This temperature range of this process is typically $350-600^{\circ} \mathrm{C}$, but the temperature for the maximum yield is most commonly around $500^{\circ} \mathrm{C}$; the residence time is shorter, approximately $2 \mathrm{~s}$, and the heating rate is higher (Wang and Jan 2018). The biomass should be dried to the level of less than $10 \%$ moisture and ground to fine particles for optimal yield and improved bio-oil quality. Bio-oil produced from fast pyrolysis usually contains 15 to $30 \mathrm{wt} \%$ water, reducing its viscosity and making it capable of combustion engines. The carboxylic acid of bio-oil has a significant effect on pH (Zhang et al., 2007). The acidity with $\mathrm{pH}=$ two to three makes the bio-oil corrosive, which imposes additional costs during the upgrading process of bio-oil before it can be used as a fuel in the transport industry.

The heart of the pyrolysis process is the reactor, where all biomass conversion reactions occur. Many reactors are used in the pyrolysis process, such as entrained flow reactors, fluidized bed reactor, fixed bed reactor, autoclave, rotating cone reactor, and plasma reactor (Garcia-Nunez et al., 2017). These reactors can be classified into subcategories according to the flow of material and phenomena, such as circulating, co-current, counter-current, and crossflow. The amount of bio-oil depends on the type of reactors being used and the operating conditions (Peacocke et al., 1994; Abu Bakar et al., 2020).

Table 1 lists the experimental work conducted by different researchers using different temperature ranges for bio-oil production from the fast pyrolysis of biomass. Chandran et al. 
TABLE 1 | Experimental work on the fast pyrolysis of biomass for bio-oil production.

\begin{tabular}{|c|c|c|c|c|}
\hline Sample & Reactor & Temperature range & Bio-oil yield & References \\
\hline Palm kernel cake & Bubbling fluidized bed reactor & $350-600^{\circ} \mathrm{C}$ & $63 \%$ at $401^{\circ} \mathrm{C}$ & Jeong et al. (2020) \\
\hline Prosospis juliflora & Continuous blade type reactor & $350-800 \mathrm{C}$ & $50.2 \%$ at $450 \mathrm{C}$ & Chandran et al. (2020) \\
\hline Sawdust, Empty fruit bunch, Miscanthus & Circulating fluidized bed reactor & $400-600 \mathrm{C}$ & $60 \%$ at $500{ }^{\circ} \mathrm{C}$ & Park et al. (2019) \\
\hline Pomegranate marcs (PM) and grape marcs (GM) & Fixed bed reactor & $400-600 \mathrm{C}$ & $43.7 \%$ at $500 \mathrm{C}$ & Ateş et al. (2019) \\
\hline Rape straw & Continuous bubbling fluidized bed reactor & $450-550 \mathrm{C}$ & $41.39 \%$ at $480 \mathrm{C}$ & Gómez et al. (2018) \\
\hline Sugarcane bagasse & Batch pyrolysis reactor & $653-1053 \mathrm{~K}$ & $50.89 \%$ at $753 \mathrm{~K}$ & Al Arni, (2018) \\
\hline Sewage sludge & Conical spouted bed reactor & 450-600 C & $77 \%$ at $500 \mathrm{C}$ & Alvarez et al. (2016) \\
\hline Saccharine japonica alga & Fixed-bed reactor & $350-550 \mathrm{C}$ & $40.19 \%$ at $500 \mathrm{C}$ & Ly et al. (2016) \\
\hline Corn cob, Corn Stover, Sawdust Rice straw & Microwave-assisted reactor & $400-500 \mathrm{C}$ & $42.1 \%$ & Ravikumar et al. (2017 \\
\hline Pinewood, oak wood, rice husk & Rotating cone reactor & $550-700 \mathrm{C}$ & $70 \%$ & Wagenaar et al. (1994) \\
\hline
\end{tabular}

(2020) examined the effects of temperature on the bio-oil product of a unique biomass Prosospis Juliflora. They tested its performance as a blending agent using a 35\% bio-oil blended with diesel at the diesel engine's fully loaded condition. Borges et al. (2014) reported a maximum $65 \mathrm{wt} \%$ and $64 \mathrm{wt} \%$ of bio-oil yield achieved at a temperature of $480^{\circ} \mathrm{C}$ and $490^{\circ} \mathrm{C}$, respectively, with $0.9-1.9 \mathrm{~mm}$ size feed of wood sawdust and corn stove in microwave-assisted pyrolysis and applying a vacuum of less than $100 \mathrm{mmHg}$. Chen et al. (2017) examined the influence of temperature and catalyst amount in the fast pyrolysis of cotton stalk using a fixed bed reactor. The results showed that the percentage of ketone in bio-oil increases as the $\mathrm{CaO}$ amount as catalyst increases. Furthermore, as the temperature was increased above $600^{\circ} \mathrm{C}$, the amount of bio-oil decreased, and the gaseous product increased. The bio-oil yield was higher between 500 and $600 \mathrm{C}$ despite using different types of biomass and reactors (Table $\mathbf{1}$ ).

\section{ECONOMIC ANALYSIS FOR BIO-OIL PRODUCTION}

Economic analysis involves checking or testing the economic practicability of a process or product under a progressive stage, which helps track future research, expansion, and investment (Sharma et al., 2019). Financial analysis is related to determining the price of manufacturing, selling, investing, and marketing. Furthermore, the calculated values can help predict the future cash flow and return on investment. Different types of sustainability and business models, such as the triple bottom line analysis model and pay as you go model, are available for analyzing sustainability development (Sharma et al., 2019). Economic analysis is based on methods, size of the plants (laboratory, pilot, or commercial), availability, and continuous feedstock supply. Feed supply and product cost analysis are critical challenges to making the product market compatible-several factors are involved in the economic analysis. Fixed capital investment (FCI) refers to funds used to purchase manufacturing and plant infrastructure, while working capital refers to funds used to maintain factory operations. The total capital investment is the sum of the fixed capital investment and the working capital. Manufacturing fixed capital investment (direct cost) and non-manufacturing fixed capital investment may be separated into two categories (indirect cost). Capital needed to complete the process operation, such as site preparation, piping, instrumentation and auxiliary equipment, is included in manufacturing fixed-capital investment. In contrast, non-manufacturing fixed-capital investment includes construction overhead and components unrelated to the process operation (Inayat et al., 2017). Furthermore, the total direct production cost is calculated based on feedstock and utility costs. Total product cost highly depends upon both fixed capital and total product cost.

Using a blended feedstock (mixture of two or more different biomass) is beneficial because of the massive variety in biomass selection, lower risk, and lower carriage costs (Oasmaa et al., 2010). Bio-fuel upgrading is another suitable technique for making a product commercially feasible. Fast pyrolysis and upgrading of crude bio-oil can be carried out with or without the catalyst. Several kinds of catalysts used for the bio-oil upgradation $\left(\mathrm{N}_{\mathrm{i}}\right.$, zeolite, $\mathrm{Al}_{2} \mathrm{O}_{3}, \mathrm{P}_{\mathrm{d}}, \mathrm{P}_{\mathrm{t}}, \mathrm{TiO}_{2}$, etc) (Mortensen et al., 2011; Miandad et al., 2019; Farooq et al., 2021). The catalytic bio-oil has less acidic and oxygen compounds than non-catalytic bio-oils. These properties prove that the scale-up of catalytic pyrolysis is more favorable from an economic point of view because of the lesser requirement of additional equipment (Sorunmu et al., 2020). Recycling is another route to enhancing economic potential. Research has been conducted on rape straw, corn stalks, and camphor wood, in which gases produced during the pyrolysis process are recycled (Yang et al., 2018).

Table 2 lists the techno-economic analysis presented by several researchers for bio-oil production using the fast pyrolysis of biomass. The final percentage yield of bio-oil is one of the most substantial constraints affecting process economics. Meyer et al. (2020) conducted an economic evaluation of six lignocellulosic biomass. The maximum bio-oil yield was obtained through pine, while switchgrass provided the minimum product. Wang et al. (2019) performed a techno-economic analysis of the products obtained from the cotton stalk. They concluded that the production capacity could reach approximately 18,000 tons per year with a manufacturing cost of $\$ 3 / \mathrm{kg}$. The research was conducted to determine the potential economic use of rice straw in thermochemical conversion techniques. The results showed that bio-oil production through pyrolysis from rice straw is economically viable. Usually, only $46-65 \%$ of the biomass is converted (Diehlmann et al., 2019). 
TABLE 2 | Techno-economical analysis of bio-oil produced from fast pyrolysis.

\begin{tabular}{|c|c|c|c|c|c|}
\hline Sample & $\begin{array}{l}\text { Plant size } \\
\text { or feed } \\
\text { rate }\end{array}$ & Process & Software & $\begin{array}{l}\text { Economic analysis } \\
\text { findings }\end{array}$ & References \\
\hline $\begin{array}{l}\text { Pine } \\
\text { Tulip poplar } \\
\text { Hybrid Poplar } \\
\text { Switchgrass } \\
\text { Corn stover } \\
\text { Oriented strand } \\
\text { board }\end{array}$ & $\begin{array}{l}2000 \text { tons } \\
\text { per day }\end{array}$ & $\begin{array}{l}\text { Bubbling fluidized bed reactor } \\
\text { pyrolysis oil upgrading }\end{array}$ & CHAMCAD & $\begin{array}{l}\text { Capital cost: } 30-40 \% \\
\text { Feedstock cost: } 30 \% \\
\text { Hydrotreating catalyst cost: } 13-18 \% \\
\text { Labor cost: } 12-15 \%\end{array}$ & $\begin{array}{l}\text { Meyer et al. } \\
(2020)\end{array}$ \\
\hline $\begin{array}{l}\text { Forest } \\
\text { residue }\end{array}$ & $5 \mathrm{~kg} / \mathrm{h}$ & Continuous rotatory kiln reactor & Aspen Plus & $\begin{array}{l}\text { The minimum selling price of upgraded bio-oil was } \\
\text { more than double that of crude bio-oil }\end{array}$ & $\begin{array}{l}\text { van Schalkwyk } \\
\text { et al. (2020) }\end{array}$ \\
\hline Corn cob & $\begin{array}{l}96.5 \text { ton per } \\
\text { hour }\end{array}$ & $\begin{array}{l}\text { Fluidized bed reactor and } \\
\text { hydrotreating }\end{array}$ & $\begin{array}{l}\text { PYROL } \\
\text { HYSYS }\end{array}$ & $\begin{array}{l}\text { The least tolerable product prices for the economic } \\
\text { feasibility of pyrolysis route US\$1.47/gasoline- } \\
\text { gallon-equivalent bio-oil }\end{array}$ & $\begin{array}{l}\text { Brigagão et al. } \\
\text { (2019) }\end{array}$ \\
\hline $\begin{array}{l}\text { Sugarcane } \\
\text { bagasse }\end{array}$ & 10 tons per hour & $\begin{array}{l}\text { Pyrolysis reactor and } \\
\text { hydrotreating }\end{array}$ & Aspen Plus & $\begin{array}{l}\text { Fluctuating tax charges and capital costs can not } \\
\text { disturb the least selling price as much as } \\
\text { conversion ratios }\end{array}$ & $\begin{array}{l}\text { Ramirez and } \\
\text { Rainey (2019) }\end{array}$ \\
\hline Eucalyptus & $\begin{array}{l}2000 \text { metric ton } \\
\text { per day }\end{array}$ & $\begin{array}{l}\text { Tail gas reactive pyrolysis (TGRP) } \\
\text { and electricity generation plant }\end{array}$ & Pro/ll simulator & $\begin{array}{l}\text { The results specified that pyrolysis of eucalyptus } \\
\text { for power in a single facility is not good with the } \\
\text { current electricity cost }\end{array}$ & $\begin{array}{l}\text { Pighinelli et al. } \\
\text { (2018) }\end{array}$ \\
\hline Rice husk & $\begin{array}{l}1,000 \text { tons } \\
\text { per day }\end{array}$ & fluidized-bed fast pyrolysis & Aspen Plus & $\begin{array}{l}\text { The least bio-oil selling price was intended as } \$ \\
0.55 / L\end{array}$ & $\begin{array}{l}\text { Wang and Jan } \\
\text { (2018) }\end{array}$ \\
\hline $\begin{array}{l}\text { Wheat straw } \\
\text { Corn cob } \\
\text { Sawdust }\end{array}$ & $100 \mathrm{~kg} / \mathrm{h}$ & $\begin{array}{l}\text { Internally interconnected fluidized } \\
\text { bed reactor and pretreatment unit }\end{array}$ & Aspen plus & $\begin{array}{l}\text { The mobile pyrolysis system has a better long-term } \\
\text { economy than the fixed plant due to the higher } \\
\text { turnover }\end{array}$ & Chen et al. (2018) \\
\hline Pinewood & 72 tons per day & $\begin{array}{l}\text { Pyrolysis reactor with catalytic } \\
\text { cracking }\end{array}$ & Aspen plus & $\begin{array}{l}\text { The outcomes deliver indication to the provision of } \\
\text { biofuel production's economic viability via zeolite } \\
\text { cracking of pyrolysis-derived bio-oil }\end{array}$ & $\begin{array}{l}\text { Shemfe et al. } \\
(2017)\end{array}$ \\
\hline Rice husk & $\begin{array}{l}4,000 \mathrm{~kg} \text { per } \\
\text { hour }\end{array}$ & Pretreatment Pyrolysis reactor & Aspen Plus & $\begin{array}{l}\text { The production cost of liquid fuel is less than the } \\
\text { expected selling price of pyrolysis liquid with } \\
6 \text { years payback period }\end{array}$ & Ji et al. (2017) \\
\hline $\begin{array}{l}\text { Sugarcane } \\
\text { bagasse }\end{array}$ & $\begin{array}{l}1,000 \text { tons per } \\
\text { hour }\end{array}$ & Fast pyrolysis and hydrotreating & $\begin{array}{l}\text { Financial and risk } \\
\text { analysis } \\
\text { simulator }\end{array}$ & $\begin{array}{l}\text { Fisher-Tropsch synthesis is the more efficient } \\
\text { option than the fast pyrolysis approach }\end{array}$ & $\begin{array}{l}\text { Michailos et al. } \\
\text { (2017) }\end{array}$ \\
\hline Forest residue & $\begin{array}{l}2000 \text { dry metric } \\
\text { tons per day }\end{array}$ & $\begin{array}{l}\text { Pyrolysis reactor } \\
\text { hydrothermal treating }\end{array}$ & $\begin{array}{l}\text { Lab experiment and } \\
\text { Aspen Plus }\end{array}$ & $\begin{array}{l}\text { With a } 30 \text {-years project life, a minimum fuel selling } \\
\text { price was determined to be } 6.25 \$ \text { per gallon }\end{array}$ & $\begin{array}{l}\text { Carrasco et al. } \\
(2017)\end{array}$ \\
\hline $\begin{array}{l}\text { Empty fruit } \\
\text { bunch }\end{array}$ & $\begin{array}{l}400 \text { tons } \\
\text { per day }\end{array}$ & $\begin{array}{l}\text { Fast pyrolysis reactor } \\
\text { and upgrading unit }\end{array}$ & $\begin{array}{l}\text { A four-level economic } \\
\text { potential approach }\end{array}$ & $\begin{array}{l}\text { The bio-oil plant is the most economical due to the } \\
\text { highest economic potential for the rate of interest } \\
\text { and return rate }\end{array}$ & $\begin{array}{l}\text { Do and Lim } \\
\text { (2016) }\end{array}$ \\
\hline
\end{tabular}

\section{BIO-OIL PRODUCTION COST AND LIFE CYCLE ANALYSIS}

Economic analysis is mainly based upon capital cost and cash flow analysis, as shown in Figure 2 (Mohammed et al., 2019). This analysis will help determine the investment required to run a plant every year and the production cost of bio-oil (Rogers and Brammer, 2012). The cost can be calculated by capacity factored (heat and mass balances, power supplies, size) and equipment-based assessment and quotation from vendors (Uslu et al., 2008). Sensitivity and uncertainty analysis is dependent on the fluctuations of the price rate of different parameters, such as feedstock, labor, electricity, taxes, and total plant running time (Oudenhoven et al., 2016).
The additional economic analysis leads to the production cost of bio-oil, which can be compared with fuel produced from other sources and methods (Jaroenkhasemmeesuk and Tippayawong, 2015). This can be reduced by applying different pretreatments, upgrading, and recycling techniques. The sale of by-products produced in biomass pyrolysis, such as biochar, can reduce the bio-oil production cost by $18 \%$ (Rogers and Brammer, 2012).

Operations cost, payback period, and break-even analysis are used to examine the link between anticipated project cost and the rate of return. Entire revenue and total costs must be equal for a company to break even, which is known as the breakeven point. A point at which the projected selling revenues plus the anticipated sale proceeds after upgrading are equal to production costs 


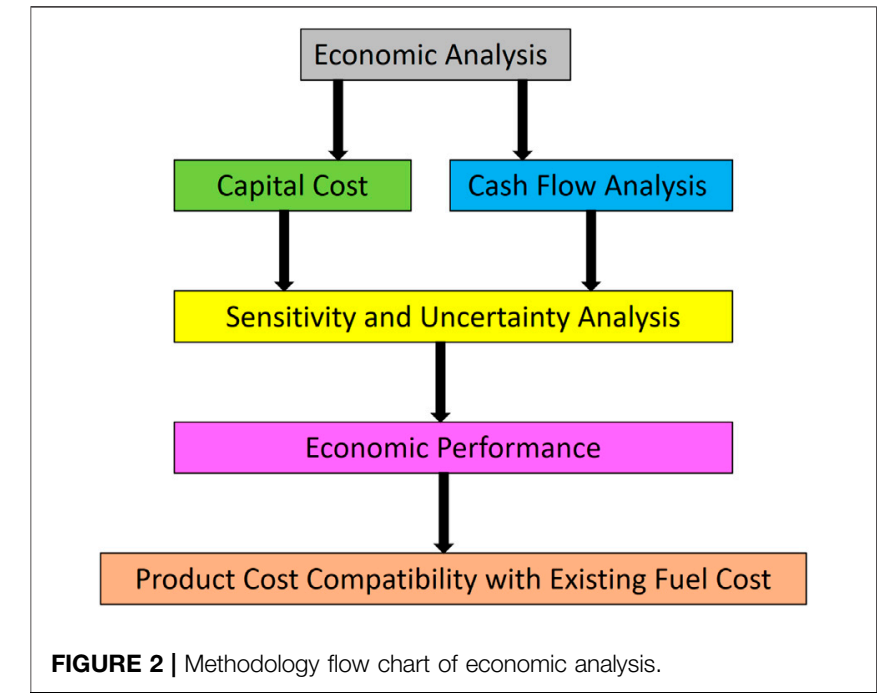

(Jaroenkhasemmeesuk and Tippayawong, 2015). The plant's lowest break-even selling point may be attained by employing the most inexpensive biomass available. The minimal feasible price for a given plant size was the risk event with the most significant break-even selling point (Rogers and Brammer, 2012).
Table 3 lists the cost of bio-oil produced from the fast pyrolysis of diverse types of biomass. Patel et al. (Patel et al., 2019) examined bio-oil production cost from the fast pyrolysis of 2000 tons per day woodchips and reported $1.09 \$ / \mathrm{L}$. They also tested the feasible plant size optimization from 500 to 5,000 tons per day and determined that a 3,000 tons per day capacity is well suited based on economic analysis. Xin et al. (2016) performed an economic analysis to determine the cost of bio-oil and coproducts using a unique approach (cultivating, harvesting, dewatering, fast pyrolysis, and bio-oil utilization of water-based waste algae and estimated a price of $\$ 2.23$ /gallon bio-oil, which is an almost acceptable level. The return rate could surge to $18.7 \%$ if three grave mechanisms, such as cultivation, harvest, and conversion, can be advanced. Li et al. (2015) conducted a cost analysis of biomass in in-situ and ex-situ catalytic pyrolysis. The least fuel-selling price of bio-oil from the in situ process was $\$ 1.11$ per liter, whereas the ex-situ process was $\$ 1.13$ per liter. Heat integration application in pyrolysis leads to the sustainability of the process via energy recovery and reduces the overall process's utilities cost. The overall pyrolysis process is endothermic, and heat is required for the complete the significant reactions. The combustible gases produced as a co-product during fast pyrolysis can also provide the process heat. These approaches reduce the overall utilities and operation cost, which positively affect

\begin{tabular}{|c|c|c|c|c|}
\hline Source of bio-oil & Process & Capacity & Cost of bio-oil & Ref \\
\hline $\begin{array}{l}\text { Municipal sewage } \\
\text { sludge }\end{array}$ & $\begin{array}{l}\text { Pyrolysis, Gas Chromatography, Mass } \\
\text { Spectroscopy } \\
\text { Aspen Plus }\end{array}$ & $50 \mathrm{~kg} / \mathrm{h}$ & $3.130(€ / \mathrm{kg})$ & $\begin{array}{l}\text { Shahbeig and Nosrati } \\
(2020)\end{array}$ \\
\hline $\begin{array}{l}\text { Napier grass } \\
\text { bagasse }\end{array}$ & $\begin{array}{l}\text { Pyrolysis } \\
\text { In situ hydrodeoxygenation }\end{array}$ & $49 \mathrm{~kg} / \mathrm{h}$ & $\begin{array}{l}\text { \$ 5.81/gallon (\$ } 1.45 / L) \text { gasoline } \\
\text { equivalent }\end{array}$ & $\begin{array}{l}\text { Mohammed et al. } \\
\text { (2019) }\end{array}$ \\
\hline Horse manure & Tail gas reactive pyrolysis (TGRP) & 200 metric dry ton per day & $\begin{array}{l}\left(\$ 1.35-\$ 1.80 \mathrm{~L}^{-1}\right) \text { of jet fuel by } \\
\text { upgraded bio-oil }\end{array}$ & Sorunmu et al. (2017) \\
\hline Pine & $\begin{array}{l}\text { Pretreatment } \\
\text { Fast pyrolysis } \\
\text { Catalytic upgrading } \\
\text { Heat integration }\end{array}$ & 1,000 dry metric ton per day & $\begin{array}{l}4.01-4.78 \$ / \text { gal for the heat- } \\
\text { integrated process } \\
4.70-6.84 \$ \text { gal without heat } \\
\text { integration }\end{array}$ & Winjobi et al. (2017) \\
\hline Beechwood & $\begin{array}{l}\text { Pre-treatment } \\
\text { Catalytic circulating fluidized bed reactor }\end{array}$ & $500 \mathrm{MT} /$ day & 2.32-3.08 \$/gallons & Vasalos et al. (2016) \\
\hline Pinewood & $\begin{array}{l}\text { Fast pyrolysis } \\
\text { Hydro processing } \\
\text { Economic analyzer }\end{array}$ & 72 MT/day & $£$ 6.25/GGE & Shemfe et al. (2015) \\
\hline Red oak & $\begin{array}{l}\text { Fast pyrolysis } \\
\text { Five-stage fractionation system }\end{array}$ & 2000 dry metric tons per day & \$ 3.09/gallon & Hu et al. (2016) \\
\hline Microalgae & $\begin{array}{l}\text { Pretreatment } \\
\text { Catalytic Pyrolysis } \\
\text { Chemical process modeling }\end{array}$ & 2000 MT per day & $\$ 1.49$ and $\$ 1.80$ per liter & $\begin{array}{l}\text { Thilakaratne et al. } \\
\text { (2014) }\end{array}$ \\
\hline
\end{tabular}


the bio-oil production cost. Economic analysis showed that the operating cost of the process was decreased using blended feedstock. Catalytic upgrading contributes to the operational cost and can be reduced using a less expensive catalyst. Furthermore, pyrolysis plants with a higher capacity can produce less expansive bio-oil than smaller plants. In addition, downstream methods, such as solvent addition, emulsification, electrolytic, and electrochemical processes for upgrading bio-oil should be developed for a cost-effective process (Kumar and Strezov, 2021).

Bio-oil is used as a feedstock for boiler and heavy-duty engines. Furthermore, bio-oil is also used as a feedstock to produce several products, such as hydrogen, chemicals, binder for electrodes, and plastics. Bio-oil is commonly used for boilers as an alternative to furnace oil because of the advantages of low emissions (Hou et al., 2016). From an economic point of view, the direct burning of bio-oil in boilers for heating is considered competitive with fossil fuels (Brammer et al., 2006). Co-firing bio-oil with conventional fuels is energy-efficient and costeffective. Particular burner technologies, such as duel block systems, have been adopted in commercial plants for bio-oil burning (Lehto et al., 2014). Bio-oil is also considered a potential candidate for hydrogen production via catalytic cracking commercially (Wang et al., 2013). In addition, several chemicals and solvents can be produced from bio-oil on a commercial scale via distillation. In bio-oil applications, the cost is considered the main barrier to the commercialization of bio-oil on a large scale.

For biomass conversion pyrolysis processes, life cycle assessment (LCA) is widely accepted as a valuable framework for analyzing environmental, human, and natural resource effects (Iribarren et al., 2012; Opatokun et al., 2017). For long-term strategic policy and environmental sustainability, it delivers scientific proof data. The LCA professionals and decision-makers have to find the paths to environmental sustainability and energy efficiency while considering the concepts simulated in the research (Osman et al., 2021). Han et al. (2013) performed LCA for the pyrolysis process using a well-wheel approach. The greenhouse gases (GHG) emissions were reduced to $112 \%$ using the pyrolysis process. Meyer et al. (2020) studied the LFA with the effect of feedstock composition on the fast pyrolysis process and evaluated the GHG and economic analysis. Field to wheel approach used for data generation. Pyrolysis oil upgrading, electricity used in the pyrolysis process, energy used in biomass harvesting and processing are the essential variables in GHG emissions. GHG elimination may not always be in the best interest of the economy.

\section{REFERENCES}

Abu Bakar, M. S., Ahmed, A., Jeffery, D. M., Hidayat, S., Sukri, R. S., Mahlia, T. M. I., et al. (2020). Pyrolysis of Solid Waste Residues from Lemon Myrtle Essential Oils Extraction for Bio-Oil Production. Bioresour. Tech. 318, 123913. doi:10.1016/j.biortech.2020.123913

\section{CONCLUSION}

Fast pyrolysis is the most beneficial method to extract bio-oil products from biomass feedstock. Bio-oil and its properties differ considerably depending on the feedstock configuration and structure, residence time, and temperature. Several research articles have been published on optimizing bio-oil production from various biomasses using a fast pyrolysis process under different operating conditions. Few reports on economic analysis of the fast pyrolysis process make it commercially stable. This review article evaluated fast pyrolysis's technical and economic routine to produce bio-oils from various biomass. A series of aspects, such as plant life expectancy, raw feed, technological parameters, and biomass price, regulate the economic stability of bio-oil production from fast pyrolysis. The temperature range from 500 to $600 \mathrm{C}$ produces a higher bio-oil yield, reducing overall production cost. The production cost of bio-oil is the critical factor for evaluating the market compatibility with other biofuels available. The cost can be affected by different pretreatments, upgrading processes, and recycling techniques. The torrefaction of biomass as a pretreatment and upgrading of bio-oil using a less expensive catalyst will lead to cost-effective biomass pyrolysis for bio-oil production. A selfsustained pyrolysis process can reduce the bio-oil production cost and is most economical on a commercial scale. This review can aid future studies on bio-oil production in terms of the commercial sector's economic benefits. Furthermore, there is a need to develop systematic autonomous algorithms required for the prediction of minimum bio-oil production cost based on the parametric study.

\section{AUTHOR CONTRIBUTIONS}

AI and AA developed the conceptualization and methodology of the study. RT and Y-KP managed resources, provided supervision and valuable research insights into the study. FJ, and SA provided literature resources and helped in analysis. CG contributed to the writing and provided valuable research insights. All authors have read and agreed to the published version of the manuscript.

\section{FUNDING}

The authors would like to acknowledge the financial support from the University of Sharjah, United Arab Emirates, through the Competitive Research Project (1602040654-P). Also, the support from the National Research Foundation of Korea under the projects (NRF-2020R1I1A1A01072793, NRF2020M1A2A2079801) is gratefully acknowledged.

Adams, P., Bridgwater, T., Lea-Langton, A., Ross, A., and Watson, I. (2018). "Biomass Conversion Technologies," in Greenhouse Gas Balances of Bioenergy Systems. Editors P. Thornley and P. Adams (Cambridge, Massachusetts, US: Academic Press), 107-139. doi:10.1016/b978-0-08101036-5.00008-2

Al Arni, S. (2018). Comparison of Slow and Fast Pyrolysis for Converting Biomass into Fuel. Renew. Energ. 124, 197-201. doi:10.1016/j.renene.2017.04.060 
Alvarez, J., Lopez, G., Amutio, M., Artetxe, M., Barbarias, I., Arregi, A., et al. (2016). Characterization of the Bio-Oil Obtained by Fast Pyrolysis of Sewage Sludge in a Conical Spouted Bed Reactor. Fuel Process. Tech. 149, 169-175. doi:10.1016/ j.fuproc.2016.04.015

Ateş, F., Büyüktuncer, H., Yaşar, B., Işık, A., Biricik, G., and Koparal, A. S. (2019). Comparison of Non-catalytic and Catalytic Fast Pyrolysis of Pomegranate and Grape Marcs under Vacuum and Inert Atmospheres. Fuel 255, 115788. doi:10.1016/j.fuel.2019.115788

Boran, F. E. (2018). A New Approach for Evaluation of Renewable Energy Resources: A Case of Turkey. Energ. Sourc. B: Econ. Plann. Pol. 13, 196-204. doi:10.1080/15567249.2017.1423414

Borges, F. C., Du, Z., Xie, Q., Trierweiler, J. O., Cheng, Y., Wan, Y., et al. (2014). Fast Microwave Assisted Pyrolysis of Biomass Using Microwave Absorbent. Bioresour. Tech. 156, 267-274. doi:10.1016/j.biortech.2014.01.038

Brammer, J. G., Lauer, M., and Bridgwater, A. V. (2006). Opportunities for Biomass-Derived "Bio-Oil" in European Heat and Power Markets. Energy Policy 34, 2871-2880. doi:10.1016/j.enpol.2005.05.005

Bridgwater, A. V. (2012). Review of Fast Pyrolysis of Biomass and Product Upgrading. Biomass and Bioenergy 38, 68-94. doi:10.1016/ j.biombioe.2011.01.048

Bridgwater, A. V. (2017). "Biomass Conversion Technologies: Fast Pyrolysis Liquids from Biomass: Quality and Upgrading," in Biorefineries: Targeting Energy, High Value Products and Waste Valorisation. Editors M. Rabaçal, A.F. Ferreira, C.A.M. Silva, and M. Costa (Cham: Springer International Publishing), 55-98. doi:10.1007/978-3-319-48288-0_3

Brigagão, G. V., de Queiroz Fernandes Araújo, O., De Medeiros, J. L., Mikulcic, H., and Duic, N. (2019). A Techno-Economic Analysis of Thermochemical Pathways for Corncob-To-Energy: Fast Pyrolysis to Bio-Oil, Gasification to Methanol and Combustion to Electricity. Fuel Process. Tech. 193, 102-113. doi:10.1016/j.fuproc.2019.05.011

Carrasco, J. L., Gunukula, S., Boateng, A. A., Mullen, C. A., Desisto, W. J., and Wheeler, M. C. (2017). Pyrolysis of forest Residues: An Approach to TechnoEconomics for Bio-Fuel Production. Fuel 193, 477-484. doi:10.1016/ j.fuel.2016.12.063

Chandran, R., Kaliaperumal, R., Balakrishnan, S., Britten, A. J., Macinnis, J., and Mkandawire, M. (2020). Characteristics of Bio-Oil from Continuous Fast Pyrolysis of Prosopis Juliflora. Energy 190, 116387. doi:10.1016/ j.energy.2019.116387

Chen, X., Chen, Y., Yang, H., Chen, W., Wang, X., and Chen, H. (2017). Fast Pyrolysis of Cotton Stalk Biomass Using Calcium Oxide. Bioresour. Tech. 233, 15-20. doi:10.1016/j.biortech.2017.02.070

Chen, X., Zhang, H., and Xiao, R. (2018). Mobile Autothermal Pyrolysis System for Local Biomass Conversion: Process Simulation and Techno-Economic Analysis. Energy Fuels 32, 4178-4188. doi:10.1021/acs.energyfuels.7b03172

Chen, X., Chen, Y., Yang, H., Wang, X., Che, Q., Chen, W., et al. (2019). Catalytic Fast Pyrolysis of Biomass: Selective Deoxygenation to Balance the Quality and Yield of Bio-Oil. Bioresour. Tech. 273, 153-158. doi:10.1016/ j.biortech.2018.11.008

Czernik, S., and Bridgwater, A. V. (2004). Overview of Applications of Biomass Fast Pyrolysis Oil. Energy Fuels 18, 590-598. doi:10.1021/ef034067u

Diehlmann, F., Zimmer, T., Glöser-Chahoud, S., Wiens, M., and Schultmann, F. (2019). Techno-Economic Assessment of Utilization Pathways for rice Straw: A Simulation-Optimization Approach. J. Clean. Prod. 230, 1329-1343. doi:10.1016/j.jclepro.2019.04.369

Do, T. X., and Lim, Y.-I. (2016). Techno-Economic Comparison of Three Energy Conversion Pathways from Empty Fruit Bunches. Renew. Energ. 90, 307-318. doi:10.1016/j.renene.2016.01.030

Farooq, W., Ali, I., Raza Naqvi, S., Sajid, M., Abbas Khan, H., and Adamu, S. (2021). Evolved Gas Analysis and Kinetics of Catalytic and Non-Catalytic Pyrolysis of Microalgae Chlorella Sp. Biomass with Ni/ $/$-Al2O3 Catalyst via Thermogravimetric Analysis. Front. Energ. Res. 9, 775037. doi:10.3389/ fenrg.2021.775037

Garcia-Nunez, J. A., Pelaez-Samaniego, M. R., Garcia-Perez, M. E., Fonts, I., Abrego, J., Westerhof, R. J. M., et al. (2017). Historical Developments of Pyrolysis Reactors: A Review. Energy Fuels 31, 5751-5775. doi:10.1021/ acs.energyfuels.7b00641

Ghenai, C., Inayat, A., Shanableh, A., Al-Sarairah, E., and Janajreh, I. (2019). Combustion and Emissions Analysis of Spent Pot Lining (SPL) as Alternative
Fuel in Cement Industry. Sci. Total Environ. 684, 519-526. doi:10.1016/ j.scitotenv.2019.05.157

Gómez, N., Banks, S. W., Nowakowski, D. J., Rosas, J. G., Cara, J., Sánchez, M. E., et al. (2018). Effect of Temperature on Product Performance of a High Ash Biomass during Fast Pyrolysis and its Bio-Oil Storage Evaluation. Fuel Process. Tech. 172, 97-105. doi:10.1016/j.fuproc.2017.11.021

Han, J., Elgowainy, A., Dunn, J. B., and Wang, M. Q. (2013). Life Cycle Analysis of Fuel Production from Fast Pyrolysis of Biomass. Bioresour. Tech. 133, 421-428. doi:10.1016/j.biortech.2013.01.141

Hou, S.-S., Huang, W.-C., Rizal, F., and Lin, T.-H. (2016). Co-Firing of Fast Pyrolysis Bio-Oil and Heavy Fuel Oil in a 300-kWth Furnace. Appl. Sci. 6, 326. doi:10.3390/app6110326

Hu, W., Dang, Q., Rover, M., Brown, R. C., and Wright, M. M. (2016). Comparative Techno-Economic Analysis of Advanced Biofuels, Biochemicals, and Hydrocarbon Chemicals via the Fast Pyrolysis Platform. Biofuels 7, 57-67. doi:10.1080/17597269.2015.1118780

Inayat, A., Ahmad, M. M., Mutalib, M. I. A., Yusup, S., and Khan, Z. (2017). Economic Analysis and Optimization for Bio-Hydrogen Production from Oil palm Waste via Steam Gasification. Energ. Sourc. Part B: Econ. Plann. Pol. 12, 158-165. doi:10.1080/15567249.2014.937881

Inayat, A., Inayat, M., Shahbaz, M., Sulaiman, S. A., Raza, M., and Yusup, S. (2020). Parametric Analysis and Optimization for the Catalytic Air Gasification of palm Kernel Shell Using Coal Bottom Ash as Catalyst. Renew. Energ. 145, 671-681. doi:10.1016/j.renene.2019.06.104

Iribarren, D., Peters, J. F., and Dufour, J. (2012). Life Cycle Assessment of Transportation Fuels from Biomass Pyrolysis. Fuel 97, 812-821. doi:10.1016/j.fuel.2012.02.053

Jaroenkhasemmeesuk, C., and Tippayawong, N. (2015). Technical and Economic Analysis of A Biomass Pyrolysis Plant. Energ. Proced. 79, 950-955. doi:10.1016/ j.egypro.2015.11.592

Jeong, J.-Y., Yang, C.-W., Lee, U.-D., and Jeong, S.-H. (2020). Characteristics of the Pyrolytic Products from the Fast Pyrolysis of palm Kernel Cake in a BenchScale Fluidized Bed Reactor. J. Anal. Appl. Pyrolysis 145, 104708. doi:10.1016/ j.jaap. 2019.104708

Ji, L.-Q., Zhang, C., and Fang, J.-Q. (2017). Economic Analysis of Converting of Waste Agricultural Biomass into Liquid Fuel: A Case Study on a Biofuel Plant in China. Renew. Sust. Energ. Rev. 70, 224-229. doi:10.1016/j.rser.2016.11.189

Kim, Y., and Parker, W. (2008). A Technical and Economic Evaluation of the Pyrolysis of Sewage Sludge for the Production of Bio-Oil. Bioresour. Tech. 99, 1409-1416. doi:10.1016/j.biortech.2007.01.056

Kumar, R., and Strezov, V. (2021). Thermochemical Production of Bio-Oil: A Review of Downstream Processing Technologies for Bio-Oil Upgrading, Production of Hydrogen and High Value-Added Products. Renew. Sust. Energ. Rev. 135, 110152. doi:10.1016/j.rser.2020.110152

Lehto, J., Oasmaa, A., Solantausta, Y., Kytö, M., and Chiaramonti, D. (2014). Review of Fuel Oil Quality and Combustion of Fast Pyrolysis Bio-Oils from Lignocellulosic Biomass. Appl. Energ. 116, 178-190. doi:10.1016/ j.apenergy.2013.11.040

Li, S., Xu, S., Liu, S., Yang, C., and Lu, Q. (2004). Fast Pyrolysis of Biomass in FreeFall Reactor for Hydrogen-Rich Gas. Fuel Process. Tech. 85, 1201-1211. doi:10.1016/j.fuproc.2003.11.043

Li, B., Ou, L., Dang, Q., Meyer, P., Jones, S., Brown, R., et al. (2015). TechnoEconomic and Uncertainty Analysis of In Situ and Ex Situ Fast Pyrolysis for Biofuel Production. Bioresour. Tech. 196, 49-56. doi:10.1016/ j.biortech.2015.07.073

Li, W., Dang, Q., Brown, R. C., Laird, D., and Wright, M. M. (2017). The Impacts of Biomass Properties on Pyrolysis Yields, Economic and Environmental Performance of the Pyrolysis-Bioenergy-Biochar Platform to Carbon Negative Energy. Bioresour. Tech. 241, 959-968. doi:10.1016/ j.biortech.2017.06.049

Ly, H. V., Kim, S.-S., Choi, J. H., Woo, H. C., and Kim, J. (2016). Fast Pyrolysis of Saccharina Japonica Alga in a Fixed-Bed Reactor for Bio-Oil Production. Energ. Convers. Manag. 122, 526-534. doi:10.1016/ j.enconman.2016.06.019

Marathe, P. S., Westerhof, R. J. M., and Kersten, S. R. A. (2020). Effect of Pressure and Hot Vapor Residence Time on the Fast Pyrolysis of Biomass: Experiments and Modeling. Energy Fuels 34, 1773-1780. doi:10.1021/ acs.energyfuels. $9 \mathrm{~b} 03193$ 
Meyer, P. A., Snowden-Swan, L. J., Jones, S. B., Rappé, K. G., and Hartley, D. S. (2020). The Effect of Feedstock Composition on Fast Pyrolysis and Upgrading to Transportation Fuels: Techno-Economic Analysis and Greenhouse Gas Life Cycle Analysis. Fuel 259, 116218. doi:10.1016/j.fuel.2019.116218

Miandad, R., Rehan, M., Barakat, M. A., Aburiazaiza, A. S., Khan, H., Ismail, I. M. I., et al. (2019). Catalytic Pyrolysis of Plastic Waste: Moving toward Pyrolysis Based Biorefineries. Front. Energ. Res. 7. doi:10.3389/fenrg.2019.00027

Michailos, S., Parker, D., and Webb, C. (2017). A Techno-Economic Comparison of Fischer-Tropsch and Fast Pyrolysis as Ways of Utilizing Sugar Cane Bagasse in Transportation Fuels Production. Chem. Eng. Res. Des. 118, 206-214. doi:10.1016/j.cherd.2017.01.001

Mohammed, I. Y., Abakr, Y. A., and Mokaya, R. (2019). Integrated Biomass Thermochemical Conversion for Clean Energy Production: Process Design and Economic Analysis. J. Environ. Chem. Eng. 7, 103093. doi:10.1016/ j.jece.2019.103093

Mortensen, P. M., Grunwaldt, J.-D., Jensen, P. A., Knudsen, K. G., and Jensen, A. D. (2011). A Review of Catalytic Upgrading of Bio-Oil to Engine Fuels. Appl. Catal. A: Gen. 407, 1-19. doi:10.1016/j.apcata.2011.08.046

Nachenius, R. W., Ronsse, F., Venderbosch, R. H., and Prins, W. (2013). "Biomass Pyrolysis," in Advances in Chemical Engineering. Editor D. Y. Murzin (Cambridge, Massachusetts, US: Academic Press), 75-139. doi:10.1016/ b978-0-12-386505-2.00002-x

Naik, S. N., Goud, V. V., Rout, P. K., and Dalai, A. K. (2010). Production of First and Second Generation Biofuels: A Comprehensive Review. Renew. Sust. Energ. Rev. 14, 578-597. doi:10.1016/j.rser.2009.10.003

Nzihou, A., Stanmore, B., Lyczko, N., and Minh, D. P. (2019). The Catalytic Effect of Inherent and Adsorbed Metals on the Fast/Flash Pyrolysis of Biomass: A Review. Energy 170, 326-337. doi:10.1016/j.energy.2018.12.174

Oasmaa, A., Solantausta, Y., Arpiainen, V., Kuoppala, E., and Sipilä, K. (2010). Fast Pyrolysis Bio-Oils from Wood and Agricultural Residues. Energy Fuels 24, 1380-1388. doi:10.1021/ef901107f

Opatokun, S. A., Lopez-Sabiron, A., Ferreira, G., and Strezov, V. (2017). Life Cycle Analysis of Energy Production from Food Waste through Anaerobic Digestion, Pyrolysis and Integrated Energy System. Sustainability 9, 1804. doi:10.3390/ su9101804

Osman, A. I., Mehta, N., Elgarahy, A. M., Al-Hinai, A., Al-Muhtaseb, A. A. H., and Rooney, D. W. (2021). Conversion of Biomass to Biofuels and Life Cycle Assessment: A Review. Environ. Chem. Lett. 19, 4075-4118. doi:10.1007/ s10311-021-01273-0

Oudenhoven, S. R. G., Van Der Ham, A. G. J., Van Den Berg, H., Westerhof, R. J. M., and Kersten, S. R. A. (2016). Using Pyrolytic Acid Leaching as a Pretreatment Step in a Biomass Fast Pyrolysis Plant: Process Design and Economic Evaluation. Biomass and Bioenergy 95, 388-404. doi:10.1016/ j.biombioe.2016.07.003

Park, J. Y., Kim, J.-K., Oh, C.-H., Park, J--W., and Kwon, E. E. (2019). Production of Bio-Oil from Fast Pyrolysis of Biomass Using a Pilot-Scale Circulating Fluidized Bed Reactor and its Characterization. J. Environ. Manage. 234, 138-144. doi:10.1016/j.jenvman.2018.12.104

Patel, M., Oyedun, A. O., Kumar, A., and Gupta, R. (2019). A Techno-Economic Assessment of Renewable Diesel and Gasoline Production from Aspen Hardwood. Waste Biomass Valor. 10, 2745-2760. doi:10.1007/s12649-0180359-x

Peacocke, G. V. C., Madrali, E. S., Li, C.-Z., Güell, A. J., Wu, F., Kandiyoti, R., et al. (1994). Effect of Reactor Configuration on the Yields and Structures of PineWood Derived Pyrolysis Liquids: A Comparison between Ablative and WireMesh Pyrolysis. Biomass and Bioenergy 7, 155-167. doi:10.1016/0961-9534(94) 00055-X

Pighinelli, A. L. M. T., Schaffer, M. A., and Boateng, A. A. (2018). Utilization of eucalyptus for Electricity Production in Brazil via Fast Pyrolysis: A TechnoEconomic Analysis. Renew. Energ. 119, 590-597. doi:10.1016/j.renene.2017.12.036

Ramirez, J. A., and Rainey, T. J. (2019). Comparative Techno-Economic Analysis of Biofuel Production through Gasification, Thermal Liquefaction and Pyrolysis of Sugarcane Bagasse. J. Clean. Prod. 229, 513-527. doi:10.1016/ j.jclepro.2019.05.017

Ravikumar, C., Senthil Kumar, P., Subhashni, S. K., Tejaswini, P. V., and Varshini, V. (2017). Microwave Assisted Fast Pyrolysis of Corn Cob, Corn stover, Saw Dust and Rice Straw: Experimental Investigation on Bio-Oil Yield and High Heating Values. Sust. Mater. Tech. 11, 19-27. doi:10.1016/j.susmat.2016.12.003
Rogers, J. G., and Brammer, J. G. (2012). Estimation of the Production Cost of Fast Pyrolysis Bio-Oil. Biomass and Bioenergy 36, 208-217. doi:10.1016/ j.biombioe.2011.10.028

Shahbaz, M., Yusup, S., Pratama, A., Inayat, A., Patrick, D. O., and Ammar, M. (2016). Parametric Study and Optimization of Methane Production in Biomass Gasification in the Presence of Coal Bottom Ash. Proced. Eng. 148, 409-416. doi:10.1016/j.proeng.2016.06.432

Shahbeig, H., and Nosrati, M. (2020). Pyrolysis of Municipal Sewage Sludge for Bioenergy Production: Thermo-Kinetic Studies, Evolved Gas Analysis, and Techno-Socio-Economic Assessment. Renew. Sust. Energ. Rev. 119, 109567. doi:10.1016/j.rser.2019.109567

Sharma, A., Jakhete, A., Sharma, A., Joshi, J. B., and Pareek, V. (2019). Lowering Greenhouse Gas (GHG) Emissions: Techno-economic Analysis of Biomass Conversion to Biofuels and Value-Added Chemicals. Greenhouse Gas Sci. Technol. 9, 454-473. doi:10.1002/ghg.1867

Shemfe, M. B., Gu, S., and Ranganathan, P. (2015). Techno-Economic Performance Analysis of Biofuel Production and Miniature Electric Power Generation from Biomass Fast Pyrolysis and Bio-Oil Upgrading. Fuel 143, 361-372. doi:10.1016/ j.fuel.2014.11.078

Shemfe, M., Gu, S., and Fidalgo, B. (2017). Techno-Economic Analysis of Biofuel Production via Bio-Oil Zeolite Upgrading: An Evaluation of Two Catalyst Regeneration Systems. Biomass and Bioenergy 98, 182-193. doi:10.1016/ j.biombioe.2017.01.020

Sorunmu, Y. E., Billen, P., Elkasabi, Y., Mullen, C. A., Macken, N. A., Boateng, A. A., et al. (2017). Fuels and Chemicals from Equine-Waste-Derived Tail Gas Reactive Pyrolysis Oil: Technoeconomic Analysis, Environmental and Exergetic Life Cycle Assessment. ACS Sust. Chem. Eng. 5, 8804-8814. doi:10.1021/acssuschemeng.7b01609

Sorunmu, Y., Billen, P., and Spatari, S. (2020). A Review of Thermochemical Upgrading of Pyrolysis Bio-oil: Techno-Economic Analysis, Life Cycle Assessment, and Technology Readiness. GCB Bioenergy 12, 4-18. doi:10.1111/gcbb.12658

Tabakaev, R., Kanipa, I., Astafev, A., Dubinin, Y., Yazykov, N., Zavorin, A., et al. (2019). Thermal Enrichment of Different Types of Biomass by LowTemperature Pyrolysis. Fuel 245, 29-38. doi:10.1016/j.fuel.2019.02.049

Thilakaratne, R., Wright, M. M., and Brown, R. C. (2014). A Techno-Economic Analysis of Microalgae Remnant Catalytic Pyrolysis and Upgrading to Fuels. Fuel 128, 104-112. doi:10.1016/j.fuel.2014.02.077

Trinh, Q. T., Banerjee, A., Ansari, K. B., Dao, D. Q., Drif, A., Binh, N. T., et al. (2020). "Upgrading of Bio-Oil from Biomass Pyrolysis: Current Status and Future Development," in Biorefinery of Alternative Resources: Targeting Green Fuels and Platform Chemicals. Editors S. Nanda, D.-V. N. Vo, and P. K. Sarangi (Singapore: Springer Singapore), 317-353. doi:10.1007/978981-15-1804-1_14

Uslu, A., Faaij, A. P. C., and Bergman, P. C. A. (2008). Pre-treatment Technologies, and Their Effect on International Bioenergy Supply Chain Logistics. TechnoEconomic Evaluation of Torrefaction, Fast Pyrolysis and Pelletisation. Energy 33, 1206-1223. doi:10.1016/j.energy.2008.03.007

Van Schalkwyk, D. L., Mandegari, M., Farzad, S., and Görgens, J. F. (2020). Techno-Economic and Environmental Analysis of Bio-Oil Production from forest Residues via Non-Catalytic and Catalytic Pyrolysis Processes. Energ. Convers. Manag. 213, 112815. doi:10.1016/j.enconman.2020.112815

Vasalos, I. A., Lappas, A. A., Kopalidou, E. P., and Kalogiannis, K. G. (2016). Biomass Catalytic Pyrolysis: Process Design and Economic Analysis. Wires Energ. Environ 5, 370-383. doi:10.1002/wene.192

Wagenaar, B. M., Prins, W., and Van Swaaij, W. P. M. (1994). Pyrolysis of Biomass in the Rotating Cone Reactor: Modelling and Experimental Justification. Chem. Eng. Sci. 49, 5109-5126. doi:10.1016/0009-2509(94)00392-0

Wang, W.-C., and Jan, J.-J. (2018). From Laboratory to Pilot: Design Concept and Techno-Economic Analyses of the Fluidized Bed Fast Pyrolysis of Biomass. Energy 155, 139-151. doi:10.1016/j.energy.2018.05.012

Wang, S., Li, X., Zhang, F., Cai, Q., Wang, Y., and Luo, Z. (2013). Bio-Oil Catalytic Reforming without Steam Addition: Application to Hydrogen Production and Studies on its Mechanism. Int. J. Hydrogen Energ. 38, 16038-16047. doi:10.1016/ j.ijhydene.2013.10.032

Wang, J., Lu, Z., and Shah, A. (2019). Techno-Economic Analysis of Levoglucosan Production via Fast Pyrolysis of Cotton Straw in China. Biofuels, Bioprod. Bioref. 13, 1085-1097. doi:10.1002/bbb.2004 
Winjobi, O., Shonnard, D. R., and Zhou, W. (2017). Production of Hydrocarbon Fuel Using Two-Step Torrefaction and Fast Pyrolysis of Pine. Part 1: TechnoEconomic Analysis. ACS Sust. Chem. Eng. 5, 4529-4540. doi:10.1021/ acssuschemeng.7b00372

Xin, C., Addy, M. M., Zhao, J., Cheng, Y., Cheng, S., Mu, D., et al. (2016). Comprehensive Techno-Economic Analysis of Wastewater-Based Algal Biofuel Production: A Case Study. Bioresour. Tech. 211, 584-593. doi:10.1016/ j.biortech.2016.03.102

Xin, C., Addy, M. M., Zhao, J., Cheng, Y., Ma, Y., Liu, S., et al. (2018). Waste-toBiofuel Integrated System and its Comprehensive Techno-Economic Assessment in Wastewater Treatment Plants. Bioresour. Tech. 250, 523-531. doi:10.1016/j.biortech.2017.11.040

Yang, M., Luo, B., Shao, J., Zeng, K., Zhang, X., Yang, H., et al. (2018). The Influence of CO2 on Biomass Fast Pyrolysis at Medium Temperatures. J. Renew. Sust. Energ. 10, 013108. doi:10.1063/1.5005013

Zhang, Q., Chang, J., Wang, T., and Xu, Y. (2007). Review of Biomass Pyrolysis Oil Properties and Upgrading Research. Energ. Convers. Manag. 48, 87-92. doi:10.1016/j.enconman.2006.05.010

Zhang, H., Xiao, R., Wang, D., He, G., Shao, S., Zhang, J., et al. (2011). Biomass Fast Pyrolysis in a Fluidized Bed Reactor under N2, CO2, CO, CH4 and H2 Atmospheres. Bioresour. Tech. 102, 4258-4264. doi:10.1016/ j.biortech.2010.12.075
Zhang, Y., Brown, T. R., Hu, G., and Brown, R. C. (2013). Techno-Economic Analysis of Monosaccharide Production via Fast Pyrolysis of Lignocellulose. Bioresour. Tech. 127, 358-365. doi:10.1016 j.biortech.2012.09.070

Conflict of Interest: The authors declare that the research was conducted in the absence of any commercial or financial relationships that could be construed as a potential conflict of interest.

Publisher's Note: All claims expressed in this article are solely those of the authors and do not necessarily represent those of their affiliated organizations, or those of the publisher, the editors and the reviewers. Any product that may be evaluated in this article, or claim that may be made by its manufacturer, is not guaranteed or endorsed by the publisher.

Copyright (C) 2022 Inayat, Ahmed, Tariq, Waris, Jamil, Ahmed, Ghenai and Park. This is an open-access article distributed under the terms of the Creative Commons Attribution License (CC BY). The use, distribution or reproduction in other forums is permitted, provided the original author(s) and the copyright owner(s) are credited and that the original publication in this journal is cited, in accordance with accepted academic practice. No use, distribution or reproduction is permitted which does not comply with these terms. 